\title{
Effect of vitamin E supplementation on serum alpha tocopherol and immune status of Murrah buffalo (Bubalus bubalis) calves ${ }^{*}$
}

\author{
M. Rajeesh, R.S. Dass ${ }^{1}$, A.K. Garg and V.K. Chaturvedi ${ }^{2}$ \\ Indian Veterinary Research Institute, \\ Mineral and Vitamin Nutrition Laboratory, \\ Centre of Advanced Studies in Animal Nutrition \\ Izatnagar-243122 (UP), India
}

(Received 8 August 2007; revised version 15 November 2007; accepted 15 January 2008)

\begin{abstract}
The study evaluated the effect of graded levels of vitamin E supplementation on the serum $\alpha$-tocopherol, retinol concentrations and immune response of buffalo calves. In a completely randomized design, 15 male Murrah buffalo calves (14-15 months old; $194.0 \pm 3.5 \mathrm{~kg}$ average body weight) were divided into 3 equal groups on the basis of their body weights. All the calves were fed on wheat straw and concentrate mixture to meet their nutrients requirements. In addition, all the calves in group II and III were supplemented with 300 and 600 IU of feed grade DL$\alpha$-tocopheryl acetate/d, respectively. Blood samples were collected at zero day and subsequently at 30 days intervals up to 120 days to estimate serum $\alpha$-tocopherol and retinol concentration. To assess humoral immune response, all the buffalo calves were sensitized with formalin inactivated Pasteurella multocida antigen and blood was collected on $0,7,14,21$ and 28 days post vaccination to study antibody production using indirect ELISA, whereas cell mediated immune response of buffalo calves was assessed by in vivo delayed type hypersensitivity (DTH) reaction against phytohaemaglutinin-P (PHA-P).

Retinol concentration $(\mu \mathrm{g} / \mathrm{ml})$ in blood serum of three groups of calves was statistically similar $(\mathrm{P}>0.05)$, whereas the cumulative group mean serum $\alpha$-tocopherol concentration $(\mu \mathrm{g} / \mathrm{dl})$ was significantly $(\mathrm{P}<0.01)$ higher in vitamin $\mathrm{E}$ supplemented groups as compared to control group. The pooled mean ELISA antibody titer against Pasteurella multocida was also significantly $(\mathrm{P}<0.05)$ higher in buffalo calves given vitamin $\mathrm{E}$ as compared to control group calves, but cell mediated immune response was similar $((\mathrm{P}>0.05)$ in three groups. Results of the present study indicated that vitamin $\mathrm{E}$

\footnotetext{
${ }^{*}$ This research work was carried out under AP Cess scheme financed by Indian Council of Agricultural Research, Krishi Bhawan, New Delhi

${ }^{1}$ Corresponding author: e-mail: rsd@ivri.up.nic.in

${ }^{2}$ Division of Biological Products
} 
supplementation increased the $\alpha$-tocopherol concentration in serum and also enhanced the humoral immune response of buffalo calves.

KEY WORDS: vitamin E, serum $\alpha$-tocopherol, immune response, ELISA, buffalo calves

\section{INTRODUCTION}

Vitamin $\mathrm{E}$ is essential for growth, reproduction and prevention of various diseases and maintenance of the integrity of body tissues (Kibena and McMurray, 1996). The protective effect of vitamin $\mathrm{E}$ on animal health may be due to its role in reduction of glucocorticoids, which are known to be immunosuppressor (Orth, 1992). Many reports have indicated better health and improved immunity in animals fed vitamin E supplemented diets, as high doses of vitamin $\mathrm{E}$ have been reported to augment antibody production, stimulated by various antigens. Vitamin E supplementation at higher than recommended levels has been shown to enhance cellular (Cipriano et al., 1982) and humoral immune response (Samanta et al., 2006) in calves. More importantly, supplementation of vitamin $\mathrm{E}$ at higher levels than those currently recommended appears to be safe (Bendich and Machlin, 1988; Meydani and Hafek, 1992; Bendich, 1993). Looking into all these aspects, NRC (2001) has increased the vitamin $\mathrm{E}$ requirement of calves by 25 per cent, i.e. from $40 \mathrm{IU} / \mathrm{kg}$ of dietary DM to $50 \mathrm{IU} / \mathrm{kg} \mathrm{DM}$. Information regarding the requirement of vitamin $\mathrm{E}$ for buffalo calves and its impact on their performance is lacking. Objectives of the present investigation was to study the effect of graded levels of supplemental vitamin $\mathrm{E}$ on alpha tocopherol and retinol concentrations in blood serum and humoral and cell mediated immune responses in male buffalo calves.

\section{MATERIAL AND METHODS}

\section{Animal's management and feeding}

To carry out this experiment 15 male Murrah buffalo (Bubalus bubalis) calves were procured from Livestock Production Unit of Indian Veterinary Research Institute, Izatnagar (UP; India), and distributed in a completely randomized design in three different groups on the basis of their body weights. During the experimental period the calves were kept in well-ventilated shed with individual feeding and watering arrangements. Treatment against ecto- and endo- parasites was done before the start of experiment, and subsequently at regular intervals. All the calves were vaccinated against foot and mouth disease and Hemorrhagic septicaemia disease. Buffalo calves in three groups were fed on wheat straw and concentrate mixture to meet their nutrient requirements for a daily gain of $500 \mathrm{~g} /$ 
day as proposed by Kearl (1982). In addition, all the calves in groups II and III, were supplemented with 300 and $600 \mathrm{IU}$ of feed grade DL-alpha tocopheryl acetate/d, respectively (Imprextraco, Belgium), after mixing it well into the concentrate quota of each calf. Available green fodder $(2 \mathrm{~kg})$ was given once a week to all the calves to meet their vitamin A requirement. Clean and fresh drinking water was provided twice a day to all the animals.

Analysis of feeds for chemical composition, fibre fractions and vitamin E content

Wheat straw and concentrate mixture offered to the experimental calves were analysed for proximate principles (AOAC, 1995), fibre fractions (Van Soest et al., 1991) and retinol and alpha tocopherol concentration in blood serum by the method of Milne and Botnen (1986) using High Pressure Liquid Chromatography (Model: Shimadju, Japan).

\section{Blood collection}

About $10 \mathrm{ml}$ of blood was collected from the jugular vein of each calf at the beginning and subsequently at 30 days intervals up to 120 days of experimental feeding. Serum was separated and preserved in sterile plastic vials in deep freezer $\left(-20^{\circ} \mathrm{C}\right)$ till the completion of biochemical analysis.

\section{Humoral immune response}

After 120 days of experimental feeding all the buffalo calves were intramuscularly inoculated with a single dose $(2 \mathrm{ml})$ of Pasturella multocida oil adjuvant vaccine and blood was collected at different days $(0,7,14,21$ and 28 days) post vaccination (DPV) to study antibody production to assess their humoral immune response. About $10 \mathrm{ml}$ of blood was collected in clean-labeled test tubes and the harvested serum was carefully transferred to the clean-labeled plastic vials and stored in deep freezer for further analysis by ELISA.

\section{Preparation of experimental HS oil adjuvant vaccine}

The experimental vaccine batch was prepared in the Division of Biological Products, IVRI, Izatnagar (India). Pasteurella multocida $\mathrm{P}_{52}$ (Type Culture Lab., IVRI) was grown in six Roux flasks containing approximately $125 \mathrm{ml}$ of Brain Heart Infusion agar (Hi-Media, India). After incubation for $18 \mathrm{~h}$ at $37^{\circ} \mathrm{C}$, the growth from each flask was harvested in $10-15 \mathrm{ml}$ of sterilized $0.15 \mathrm{M}$ sodium chloride solution containing $0.5 \%(\mathrm{v} / \mathrm{v})$ formalin, using sterilized glass beads. Purity of the harvest from each flask was checked under microscope in wet film 
and after Gram staining. The pure harvests were pooled and kept at $37^{\circ} \mathrm{C}$ for $24 \mathrm{~h}$. The pure pooled harvests of $\mathrm{P}_{52}$ cells in formal saline were filtered through sterilized pad of muslin cloth and the filtrate was centrifuged at $5000 \mathrm{rpm}$ (Remi Centrifuge, India) for $15 \mathrm{~min}$. The pellet was washed three times with formal saline by centrifugation. Finally, the washed sediment was re-suspended in formal saline and matched with Brown's opacity tube No. 7. This suspension was finally mixed with oil adjuvant as per the method described by Bain et al. (1982). Sterility and safety of the experimental vaccine was tested as per the procedure laid down in schedule F1 of Indian Pharmacopia (2000) and stored at $4^{\circ} \mathrm{C}$ until used.

\section{Preparation of sonicated antigen for ELISA}

Roux flask containing Brain Heart Infusion (Hi- Media, India) was inoculated with pure nutrient broth culture of Pasteurella multocida $\mathrm{P}_{52}$ and incubated at $37^{\circ} \mathrm{C}$ for $18 \mathrm{~h}$. The culture was harvested with normal saline solution (NSS) and sterilized glass beads. Purity of harvested culture was confirmed by Gram's staining technique and the contents were centrifuged at $5000 \mathrm{rpm}$ for $30 \mathrm{~min}$. The sediments were washed twice with NSS and finally suspended in NSS for a density match with Brown's opacity tube No. 7. The antigen was disrupted by 100 -watt ultrasonic disintegrator at $6 \mu$ amplitude peak to peak for $30 \mathrm{~min}$ and used for ELISA (Almeida et al., 1979). The protein concentration was measured as described by Lowry et al. (1951) and the concentration of protein used for ELISA was $10 \mu \mathrm{g} / 50 \mu \mathrm{g}$ of the sonicated antigen.

\section{Dilution of test sera samples}

A final 1:50 dilution of serum sample was obtained by adding $5 \mu 1$ serum to $195 \mu$ of dilution buffer in each well of an uncoated protein binding 96 well micro titer plate. The diluted sera samples were allowed to equilibrate in dilution buffer for 5 min prior to transferring to antigen coated ELISA plate.

\section{Preparation of controls}

The positive control serum (against $P$. multocida) and negative control serum of calves were diluted in dilution buffer to get a dilution of 1:100. Normal nonimmunized calf serum was taken as negative control.

\section{Test proper}

For the test, the procedure laid down by Almeida et al. (1979) for ELISA was followed. Polystyrene plates (Griener, Germany) wells were covered individually 
with $50 \mu 1$ of $P$. multocida $\left(\mathrm{P}_{52}\right.$ strain) antigen containing approximately $10 \mu \mathrm{g}$ protein. Then $50 \mu 1$ of coating buffer ( $\mathrm{pH}$ 9.6) was added to each well and the plates were incubated at $4^{\circ} \mathrm{C}$ in a refrigerator for $24 \mathrm{~h}$. Excess buffer solution from the well was discarded by inversion and $50 \mu \mathrm{l}$ of methyl alcohol was added to each well and incubated at $37^{\circ} \mathrm{C}$ for $2 \mathrm{~h}$ for drying. The antigen-coated plates were washed twice with washing solution. Fifty $\mu$ l of serum dilution buffer was added to each well with the exception of first three and last three wells of the first and sixth row. Fifty $\mu 1$ of unknown diluted (1:50) serum was added to each corresponding marked well of antigen coated test plate producing a final dilution of 1:100. The plate was then incubated at $37^{\circ} \mathrm{C}$ for $2 \mathrm{~h}$. The liquid was tapped out from each well and then each well was washed with washing solution. A soaking time of 3 min was allowed and the procedure was repeated twice. A hundred $\mu 1$ of suitably diluted conjugate (antibovine HRPO conjugate, procured from National Institute of Immunology, New Delhi) was then dispensed into each assay well and the plate was incubated for 90 min at $37^{\circ} \mathrm{C}$. Again the plate was washed twice with washing solution. A hundred $\mu 1$ of substrate solution was then pipette into each test well and the plate was incubated at room temperature for $20 \mathrm{~min}$. Later $100 \mu \mathrm{l}$ of reaction stopping solution was added to each well. The ELISA plate was read with the ELISA reader (Electronic Corporation of India, Hyderabad, India) at $492 \mathrm{~nm}$ and then titer was calculated.

\section{Cell mediated immune response}

At the end of experimental feeding in vivo delayed type hypersensitivity (DTH) reaction against phytohemaglutinin-P (PHA-P) was carried out on all the buffalo calves to determine the effect of vitamin $\mathrm{E}$ supplementation on cell mediated immune response. The skin on both side of the neck was cleaned and shaved with the help of a razor, $24 \mathrm{~h}$ prior to injection, so that any inflammation occurred during the shaving or due to abrasion may subside. A hundred fifty $\mu \mathrm{g}$ of PHA-P in $200 \mu 1$ of PBS (pH 7.4) was injected intradermally at two different sites $4 \mathrm{~cm}$ apart. The difference in skin fold thickness between PHA-P injected sites and control sites were measured with the help of a Verniar caliper at 24, 48 and $72 \mathrm{~h}$ post sensitization.

\section{Statistical analysis}

Data were subjected to the test of significance between the levels of DL $\alpha$-tocopheryl acetate supplementation in the diet of calves and blood serum levels of $\alpha$-tocopherol, retinol, humoral immune response and cell mediated immune response in different groups of buffalo calves using two way analysis of variance technique (Snedecor and Cochran, 1994) and means were compared using Duncan's multiple range test (Steel and Torrie, 1980). 


\section{RESULTS AND DISCUSSION}

Chemical composition of feeds. Chemical composition of the feeds offered to buffalo calves is presented in Table 1. Results revealed significantly higher amount of crude protein and vitamin $\mathrm{E}$ in concentrate mixture as compared to wheat straw.

Table 1. Chemical composition of feeds offered to buffalo calves, $\%$ DM basis

\begin{tabular}{lcc}
\hline Attributes & Concentrate mixture & Wheat straw \\
\hline Crude protein & 23.96 & 3.98 \\
Ether extract & 1.65 & 1.30 \\
Total ash & 8.30 & 6.49 \\
Acid insoluble ash & 1.68 & 4.50 \\
Neutral detergent fibre & 36.34 & 83.12 \\
Acid detergent fibre & 10.56 & 51.18 \\
$\alpha$-tocopherol, ppm & 10.72 & 3.78 \\
\hline
\end{tabular}

${ }^{1}$ parts/100: maize 30 , soyabean cake 25 , wheat bran 42 , mineral mixture 2 , salt 1

Serum $\alpha$-tocopherol and retinol concentration.Data pertaining to the concentration $(\mu \mathrm{g} / \mathrm{dl})$ of serum $\alpha$-tocopherol and retinol $(\mu \mathrm{g} / \mathrm{ml})$ are presented in Table 2 . The cumulative group mean $\alpha$-tocopherol concentration was 110.7, 206.6 and 215.8 in group I, II and III, respectively, indicating significant $(\mathrm{P}<0.001)$ higher values in calves of group II and III as compared to control. Rapid increase in plasma $\alpha$-tocopherol level in cattle calves has been reported earlier after vitamin E supplementation (Hill et al., 1993; Chatterjee et al., 2003; Samanta et al., 2006).

Table 2. Serum $\alpha$-tocopherol and retinol concentrations in buffalo calves

\begin{tabular}{|c|c|c|c|c|c|c|c|c|c|c|}
\hline \multirow{2}{*}{ Group } & \multicolumn{5}{|c|}{ Period, days } & \multirow{2}{*}{ Mean } & \multirow{2}{*}{ SEM } & \multicolumn{3}{|c|}{$P$ value } \\
\hline & 0 & 30 & 60 & 90 & 120 & & & $\mathrm{G}$ & $\mathrm{P}$ & $\mathrm{G} \times \mathrm{P}$ \\
\hline \multicolumn{11}{|c|}{$\alpha$-Tocopherol, $\mu \mathrm{g} / \mathrm{dl}$} \\
\hline I & 111.1 & 126.4 & 92.5 & 113.2 & 110.2 & $110.7^{\mathrm{B}}$ & 13.06 & 0.000 & 0.019 & 0.348 \\
\hline II & 116.8 & 188.4 & 251.3 & 263.8 & 212.7 & $206.6^{\mathrm{A}}$ & 14.73 & & & \\
\hline III & 119.6 & 174.1 & 279.6 & 257.3 & 248.2 & $215.8^{\mathrm{A}}$ & 24.74 & & & \\
\hline mean & 115.8 & 163.0 & 207.8 & 211.4 & 190.4 & & & & & \\
\hline SEM & 17.80 & 20.64 & 32.70 & 24.65 & 28.21 & & & & & \\
\hline \multicolumn{11}{|c|}{ Retinol, $\mu \mathrm{g} / \mathrm{ml}$} \\
\hline I & 0.68 & 0.71 & 0.69 & 0.73 & 0.72 & 0.71 & 0.003 & 0.889 & 0.750 & 0.998 \\
\hline II & 0.74 & 0.70 & 0.71 & 0.70 & 0.70 & 0.71 & 0.005 & & & \\
\hline III & 0.67 & 0.68 & 0.68 & 0.68 & 0.71 & 0.68 & 0.004 & & & \\
\hline mean & 0.69 & 0.69 & 0.69 & 0.70 & 0.71 & & & & & \\
\hline SEM & 0.004 & 0.006 & 0.002 & 0.006 & 0.006 & & & & & \\
\hline
\end{tabular}

means bearing different superscripts in column differ significantly $(\mathrm{P}<0.001)$ 
Njeru et al. (1995) reported a linear increase in serum $\alpha$-tocopherol on day 3 and 14 , when vitamin $E$ was supplemented at 500,1500 or $3000 \mathrm{IU} /$ animal /day for 28 days. The cumulative group mean values of retinol $(\mu \mathrm{g} / \mathrm{ml})$ were $0.71,0.71$ and 0.68 in-group I, II and III, respectively, indicating no significant effect $(\mathrm{P}>0.05)$ of vitamin E supplementation. Similarly, Cusack et al. (2005) did not find any effect on retinol concentration in feedlot cattle supplemented with higher levels of vitamin E. Further, Shinde et al. (2007) did not observe any effect of vitamin E supplementation on retinol concentration in serum of buffalo calves. Contrary to our findings, Ezzo (1995) observed an increase in vitamin A concentration in postpartum period in vitamin E/selenium supplemented buffaloes as compared to non-supplemented buffaloes. Other workers have reported that vitamin $\mathrm{E}$ has a beneficial effect not only on vitamin A absorption (Farrell, 1980), but also its storage in the liver (Williams, 1981).

Cell mediated immune response. Skin fold thickness (SFT) of buffalo calves after sensitization with PHA-P revealed numerically higher values of SFT in group II $(0.88 \mathrm{~cm})$ and group III $(0.89 \mathrm{~cm})$ as compared to group I $(0.82 \mathrm{~cm})$, but statistically the difference was non-significant $(\mathrm{P}>0.05)$ (Table 3$)$. There was a sharp increase in SFT up to $48 \mathrm{~h}$; thereafter it reduced in all the 3 groups.

Table 3. Skin fold thickness of male buffalo calves sensitized with PHA-P

\begin{tabular}{|c|c|c|c|c|c|c|c|c|c|c|}
\hline \multirow{2}{*}{ Group } & \multicolumn{5}{|c|}{ Period, h } & \multirow{2}{*}{ Mean } & \multirow{2}{*}{ SEM } & \multicolumn{3}{|c|}{$\mathrm{P}$ value } \\
\hline & 0 & 24 & 48 & 72 & 96 & & & G & $\mathrm{P}$ & $\mathrm{G} \times \mathrm{P}$ \\
\hline I & 0.80 & 0.85 & 0.88 & 0.79 & 0.77 & 0.82 & 0.002 & 0.299 & 0.348 & 0.998 \\
\hline II & 0.82 & 0.91 & 0.91 & 0.89 & 0.86 & 0.88 & 0.005 & & & \\
\hline III & 0.79 & 0.94 & 0.97 & 0.89 & 0.86 & 0.89 & 0.003 & & & \\
\hline mean & 0.80 & 0.90 & 0.92 & 0.86 & 0.83 & 0.86 & & & & \\
\hline SEM & 0.004 & 0.005 & 0.004 & 0.005 & 0.004 & & & & & \\
\hline
\end{tabular}

Similar findings were reported by Cuesta et al. (1996) in beef cattle supplemented with vitamin E. Pehrson et al. (1991) observed no significant difference in mean lymphocyte stimulation index (LSI) against leucoagglutinin, pokeweed, and concavaline in calves supplemented with $200-600 \mathrm{mg}$ vitamin E. Similarly, Cipriano et al. (1982) did not find any significant difference in mean lymphocyte stimulation index in calves supplemented with $1 \mathrm{~g}$ of DL-alpha tocopheryl acetate/ day, when compared to control calves. Reddy et al.. (1986) reported that addition of vitamins $\mathrm{E}$ to in vitro lymphocyte cultures did not increase phytohaemagglutinineinduced blastogenesis. Similarly, Samanta et al. (2006) reported that LSI did not differ due to vitamin E supplementation in calves.

Contrary to above results, Larsen and Tollersrud (1981) observed increased response to PHA-P with lymphocytes obtained from pigs supplemented with various amounts of $\alpha$-tocopherol and sodium selenite for a period of 12 weeks. 
Corwin and Gorden (1982) reported that lymphocytes from mice supplemented with $5 \mathrm{mg}$ vitamin $\mathrm{E} / 100 \mathrm{~g}$ diet showed a 2.5 times increased response to mitogen, but supplementation with $50 \mathrm{mg}$ vitamin $\mathrm{E} / 100 \mathrm{~g}$ diet increased the response by more than eight folds. Reddy et al. (1987) reported that overall mean lymphocyte blastogenic responses to various T-cell mitogen (PHA-P, concavalin, pokeweed) and $\mathrm{B}$ cell mitogen (lipopolysaccharides) were higher in vitamin $\mathrm{E}$ supplemented calves then in control calves.

Humoral immune response. The overall mean antibody production was significantly $(\mathrm{P}<0.01)$ higher in groups II and III as compared to control group (Table 4). The pooled mean antibody titer at 14 DPV was highest in all groups,

Table 4. ELISA antibody titer of male buffalo calves vaccinated with $P$. multocida oil adjuvant vaccine

\begin{tabular}{|c|c|c|c|c|c|c|c|c|c|c|}
\hline \multirow{2}{*}{ Group } & \multicolumn{5}{|c|}{ Period, days } & \multirow{2}{*}{ Mean } & \multirow{2}{*}{ SEM } & \multicolumn{3}{|c|}{ P value } \\
\hline & 0 & 7 & 14 & 21 & 28 & & & G & $\mathrm{P}$ & $\mathrm{G} \times \mathrm{P}$ \\
\hline I & 0.14 & 0.46 & 0.61 & 0.55 & 0.47 & $0.45^{\mathrm{B}}$ & 0.08 & 0.002 & 0.000 & 0.734 \\
\hline II & 0.15 & 0.54 & 0.73 & 0.65 & 0.58 & $0.53^{\mathrm{A}}$ & 0.10 & & & \\
\hline III & 0.16 & 0.55 & 0.75 & 0.69 & 0.59 & $0.55^{\mathrm{A}}$ & 0.10 & & & \\
\hline mean & $0.15^{\mathrm{c}}$ & $0.52^{\mathrm{b}}$ & $0.68^{\mathrm{a}}$ & $0.63^{\mathrm{ab}}$ & $0.54^{\mathrm{b}}$ & & & & & \\
\hline SEM & 0.005 & 0.028 & 0.043 & 0.041 & 0.038 & & & & & \\
\hline
\end{tabular}

means bearing different superscripts in a row and columns differ significantly $(\mathrm{P}<0.01)$

which gradually decreased in all the groups. Rise in mean ELISA antibody titer was observed from 7 DPV in all the groups which peaked on 14 days post inoculation. Contrary to this Pati (1994), Mondal (1996) and Samanta et al. (2006) found the maximum ELISA titters of OAV vaccinated calves between 21 and 35 DPV, the difference may be due to species. In the present study, buffalo calves in groups II and III, which received 300 and 600 IU of DL $\alpha$-tocopheryl acetate/d showed significantly $(\mathrm{P}<0.001)$ higher antibody titer than the control group, given no supplemental vitamin $\mathrm{E}$, indicating that dietary supplementation of vitamin $\mathrm{E}$ had humoral immune enhancing effect against killed bacterial antigen. Similarly, significant immune enhancing effect of vitamin E was reported against Brucella ovis in sheep (Afzal et al., 1984; Tengerdy et al., 1991), Clostridium perfringens type D vaccine in sheep (Tengerdy et al., 1983), Mycoplasma mycoides in rabbit (Rana and Srivastava, 1999) and P. multocida whole cell vaccine in rabbit (Rawat and Jaiswal, 2004). It has been reported that vitamin $\mathrm{E}$ in water-in-oil (w/o) formulation increased antibody response due to mitogenic stimulation of $\mathrm{T}$ and $\mathrm{B}$ cells, and due to stimulation of phagocytosis (Panganmala and Cornwel, 1982). In addition, the immunostimulatory effect of vitamin $\mathrm{E}$ is also related to its antioxidant property. Tengerdy et al. (1983) observed that vitamin $\mathrm{E}$ in oil adjuvant enhanced ELISA antibody titer against Clostridium perfringens type $\mathrm{C}$ and $\mathrm{D}$ toxins much more than dietary supplementation. Mechanism of immunoenhancing effect 
of vitamin $\mathrm{E}$ administered orally or locally is probably due to higher blastogenic response of lymphocytes. Contrary to above Franchini et al. (1991) and Muneer et al. (1994) did not observe any significant beneficial effect of vitamin E on humoral immune response against E.coli in poultry and Pasteurella multocida type 6B immunization in buffalo calves. Reddy et al. (1987) also reported that there was no significant difference in mean serum anti BHV-1 antibody titers among different levels of vitamin E supplemented calves but calves given supplemental vitamin $\mathrm{E}$ showed a trend towards higher IgG response to vaccination at 7 weeks of age. Similar findings were also reported by Rivera et al. (2002) in beef cattle supplemented with vitamin $\mathrm{E}$ in their diet.

\section{CONCLUSIONS}

Results of the present study indicated that vitamin E supplementation increased the $\alpha$-tocopherol concentration in serum and also enhanced the humoral immune response of buffalo calves.

\section{ACKNOWLEDGEMENTS}

Authors are grateful to Director, Indian Veterinary Research Institute, Izatnagar, for providing the necessary facilities to carry out this research work.

\section{REFERENCES}

Afzal M.R.P., Tengerdy R.P., Ellis C.V., Kimberling E., Morris C.J., 1984. Protection of rams against epididymitis by a Brucella ovis-vitamin E adjuvant vaccine. Vet. Immunol. Immunopathol. 7, 293-304

Almedia J.D., Atanasiu P.S., Gerdner J.E., Schuurs A.W., Vollar A., Yolken R.H., 1979. Manual for Laboratory Viral Diagnosis. WHO Offset Publication No. 47. WHO, Geneva

AOAC, 1995. Association of Official Analytical Chemists, Officials Methods of Analysis. 16 $6^{\text {th }}$ Edition. Washington, DC

Bain R.V.S., DeAlwis M.C.L., Carter G.R., Gupta B.K., 1982. Hemorrhagic septicaemia. FAO, United Nations, No. 33. Rome

Bendich A., 1993. Vitamin E and human immune functions In: D.M. Klurfeld (Editor). Human Nutrition: A Comprehensive Treatise. Plenum Press, New York, pp. 411-416

Bendich A., Machlin L.J., 1988. Safety of oral intake of vitamin E. Amer. J. Clin.Nutr. 48,612-619

Chatterjee P.N., Kaur H., Panda N., 2003. Effect of vitamin E supplementation on plasma antioxidant vitamins and immunity status of crossbred cows. Asian-Austr. J. Anim. Sci. 16, 1614-1618

Cipriano J.E., Morrill J.L., Anderson N.V., 1982. Effect of dietary vitamin E on immune responses of calves. J. Dairy Sci. 65, 2357 
Corwin L.M., Gordon R.K., 1982. Vitamin E and immune regulation. Ann. N.Y. Acad. Sci. 393, 437

Cuesta P.A., McDowell L.R., Kunkle W.E., Lawman M.J., Bullock F., Drew A., Wilkinson N.S., Martin F.G., 1996. Mineral status in beef cattle, live weight changes and immune response as related to selenium and vitamin E supplementation. Livestock. Res. Rural Develop. 8, 1-7

Cusack P.M.V., McMeniman N.P., Lean J.I., 2005. The physiological and production effects of increased dietary intake of vitamin $\mathrm{E}$ and $\mathrm{C}$ in feedlot cattle challenged with bovine herpes virus 1. J. Anim. Sci. 83, 2423-2433

Ezzo O.H., 1995. The effects of vitamins and selenium supplementation on serum vitamin level and some reproductive patterns in Egyptian buffaloes during the pre and postpartum periods. Buffalo J. 10, 103-107

Indian Pharmacopia, 2000. Government of India, Ministry of Health and Welfare. The Controller of Publications, Delhi, pp. 112

Farrel P.B., 1980. Deficiency States, Pharmacological Effects and Nutrient Requirements. Marcel Decker, pp. 520- 620

Franchini A., Canti M., Manfreda G., Bertuzzi S., 1991. Vitamin E as adjuvant in emulsified vaccines for chicks. Poultry Sci. 70, 709-713

Hill G.M., Williams S.E., Williams S.N., Neel S.W., Utley P.R., 1993. Vitamin E effects on steer performance and color retention of steaks and ground beef. J. Anim. Sci. 71, Suppl. 1, 22 (Abstr.)

Kearl L.C., 1982. Nutrient Requirement of Ruminants in Developing Countries. International Feedstuffs Institute, Utah Agriculture Station, Utah State University. Logan, Utah (USA)

Kibena K.S., McMurray D.N., 1996. Nutrition and immune system: a review of nutrient-nutrient interactions. J. Amer. Diet. Assn. 96, 1156-1164

Larsen H.J., Tollersrud S., 1981. Effect of dietary vitamin E and selenium on the phytohemagglutinin response of pig lymphocytes. Res. Vet. Sci. 31, 301

Lowry O.H., Rosebrough N., Farr A.L., Randall R.J., 1951. Protein measurement with the folin phenol reagents. J. Biol. Chem. 193, 265-275

Meydani S.M., Hafek M., 1992. Vitamin E and the immune response in nutrition and immunology In: R.K. Chandra (Editor). Arts Biomedical Publ. \& Distributors, New Foundland, pp. 105-128

Milne D.B., Botnen J.R., 1986. Retinol, alpha tocopherol, lycopene and beta-carotene, simultaneously determined in plasma by isocratic liquid chromatography. Clin. Chem. 32, 874-876

Mondal B.C., 1996. Performance of crossbred (Bos indicus x Bos taurus) calves on grain less diet during milk and post milk feeding period. PhD. Thesis, Deemed University IVRI, Izatnagar (India)

Muneer R., Akhtar S., Afzal A., 1994. Evaluation of three oil adjuvant vaccines against $P$. multocida in buffalo calves. Rev. Sci. Tech. Oie. 13, 837-843

Njeru C.A., McDowell L.R., Shireman R.M., Wilkinson N.S., Rojas L.X., Williams S.N., 1995. Assessment of vitamin E nutritional status in cattle. J.Anim. Sci. 73, 1440

NRC, 2001. Nutrient Requirements of Dairy Cattle. $7^{\text {th }}$ Revised Edition. National Research Council. Washington, DC

Orth C.K., 1992. The glucocorticoids suppress immunity. New Sci. 205, 311-313

Panganmala R.V., Cornwel D.G., 1982. The effects of vitamin E on arachidonic acid metabolism. Ann. N.Y. Acad. Sci. 393, 376-390

Pati U.S., 1994. Characterization of protective antigen of Pasteurella multocida serotype 6B. MVSc. Thesis, Deemed University IVRI, Izatnagar (India)

Pehrson B., Hakkarainen J., Tornquist K.E., Fossum C., 1991. Effect of vitamin E supplementation on weight gain, immune competence, and disease incidence in barley fed cattle. J. Dairy Sci. 74, 1054-1059 
Rana R., Srivastava N.C., 1999. Immune response in rabbits (Lepus cuniculus) immunized with Mycoplasma mycoides sub sp. Capri in different adjuvant. Indian J. Vet. Res. 8, 45-53

Rawat M., Jaiswal T.N., 2004. Immunomodulation of water in oil in water (w/o/w), emulsion vaccines of killed Pasteurella multocida $\left(\mathrm{P}_{52}\right)$ whole cell grown under iron-regulated condition. Indian J. Anim. Sci. 74, 701-705

Reddy P.G., Morril J.L., Minocha H.C., Morril M.B., Dayton A.D., Frey R.A., 1986. Vitamin E is immunostimulatory in calves. J. Dairy Sci. 69,164-171

Reddy P.G., Morril J.L., Minocha H.K., Stevenson J.S., 1987. Vitamin E is immunostimulatory in calves. J. Dairy Sci. 70, 993

Rivera J.D., Duff G.C., Galyean M.L., Walker D.A., Nunnery G.A., 2002. Effect of supplemental vitamin $\mathrm{E}$ on performance, health and humoral immune response of beef cattle. J. Anim. Sci. 80, 933-941

Samanta A.K., Dass R.S., Rawat Mayank, Mishra S.C., Mehra U.R., 2006. Effect of dietary vitamin E supplementation on serum alpha tocopherol and immune status of crossbred calves. AsianAustr. J. Anim. Sci. 19, 500-506

Shinde P.L., Dass R.S., Garg A.K., Chaturvedi V.K., 2007. Immune Response and plasma Alpha tocopherol and selenium status of male buffalo (Bubalus bubalis) calves supplemented with vitamin E and selenium. Asian-Austr. J. Anim. Sci. 20, 1539-1545

Snedecor G.W., Cochran W.G., 1994. Statistical Methods. $8^{\text {th }}$ Edition. Iowa State University, Iowa (USA)

Steel R.G.D., Torrie J.H., 1980. Principles and Procedures of Statistics: A Biometrical Approach. $2^{\text {nd }}$ Edition. McGraw Hill Book Company, New York

Tengerdy R.P., Ameghino E., Riemann H., 1991. Serological response of rams to a Brucella ovis vitamin E adjuvant vaccine. Vaccine 9, 273-276

Tengerdy R.P., Meyer D.L., Lauerman L.H., Lueker D.C., Nockels C.F., 1983. Vitamin E enhanced humoral antibody response to Clostridia perfringens type D in sheep. Brit. Vet. J. 139, 147-152

Van Soest P.J., Robertson J.B., Lewis B.A., 1991. Methods of dietary fibre, neutral detergent fibre and non-starch polysaccharides in relation to animal nutrition. J. Dairy Sci. 74, 3583-3597

Williams N., 1981. Nutrition and Diet Therapy: Vitamin A (Retinol). $4^{\text {th }}$ Edition. The C.V. Mostby Company. St. Louis Toronto, London, pp. 84-100 